\title{
Hubungan Kerapatan Vegetasi dan Bangunan terhadap UHI (Urban Heat Island) di Kota Magelang
}

\section{The Relationship of Vegetation and Building Density toward UHI (Urban Heat Island) in Magelang City}

\author{
Febriyan Riyadi ${ }^{\mathrm{a}}$, Sri Rahayu ${ }^{\mathrm{b}} *$
}

\author{
${ }^{a}$ Departemen Perencanaan Wilayah dan Kota Universitas Diponegoro, Semarang, Indonesia \\ ${ }^{b}$ Departemen Perencanaan Wilayah dan Kota Universitas Diponegoro, Semarang, Indonesia
}

\begin{abstract}
Abstrak
Urban Heat Island (UHI) adalah fenomena dimana suatu wilayah perkotaan lebih panas daripada wilayah disekitarnya. Faktor utama yang mempengaruhi terjadinya UHI adalah terjadinya konversi tutupan lahan vegetasi menjadi daerah terbangun akibat perkembangan kota. Hal tersebut mengakibatkan peningkatan suhu permukaan, dikarenakan kerapatan vegetasi yang berkurang dan meningkatnya kerapatan bangunan. Perubahan tutupan lahan pada kawasan penelitian dapat di identifikasi menggunakan analisis klasifikasi tak terbimbing, selanjutnya analisis NDVI (Normalized Difference Vegetation Index) untuk mengetahui perubahan vegetasi, analisis NDBI (Normalized Difference Vegetation Index) untuk mengetahui perubahan kerapatan bangunan, serta menggunakan LST (Land Surface Temperature) untuk mengetahui suhu permukaan suatu kota dan OLS (Ordinary Least Square) merupakan permodelan regresi berganda untuk menggambarkan hubungan antar variable pada aplikasi ArcGIS. Hasil dalam penelitian ini menunjukkan bahwa suhu rata-rata Kota Magelang pada tahun 2000 sebesar $22,58^{\circ} \mathrm{C}$ meningkat menjadi $27,11^{\circ} \mathrm{C}$ pada tahun 2016. Hubungan antara kerapatan bangunan (x1) dan kerapatan vegetasi (x2) terhadap suhu permukaan (y) diketahui melalui formula OLS yang dihasilkan yaitu $\mathrm{Y}=5,61 \mathrm{X}_{1}-1,34 \mathrm{X}_{2}+2,4$. Hal ini berarti, jika kerapatan bangunan meningkat dan kerapatan vegetasi berkurang, maka suhu permukaan meningkat.
\end{abstract}

Kata kunci: Urban Heat Island, Kenaikan Suhu Permukaan, Kerapatan Vegetasi, Kerapatan Bangunan.

\begin{abstract}
Urban Heat Island (UHI) is a phenomenon where an urban area is hotter than the surrounding area. The main factor influencing the occurrence of UHI is the conversion of vegetation land cover to a built area due to urban development. This results in an increase in surface temperature, due to reduced vegetation density and increased building density. The analysis used is unsupervised classification to see changes in land cover, NDVI (Normalized Difference Vegetation Index) analysis to determine vegetation changes, NDBI (Normalized Difference Vegetation Index) analysis to determine changes in building density, and using LST (Land Surface Temperature) to determine the surface temperature of a city and OLS (Ordinary Least Square) used to determine the relationship between these variables in the ArcGis application. The results in this study indicate that the average temperature of Magelang City in 2000 was $22.58{ }^{\circ} \mathrm{C}$ which increased to $27.11^{\circ} \mathrm{C}$ in 2016 . This means that the average temperature of Magelang City increased by $4.53{ }^{\circ} \mathrm{C}$. The relationship between building density $(\mathrm{x} 1)$ and vegetation $(\mathrm{x} 2)$ to surface temperature $(\mathrm{y})$ is known through the resulting OLS formula, $\mathrm{Y}=5.61 \mathrm{X} 1-1.34 \mathrm{X} 2+2.4$. It is known that if the density of buildings increases and the density of vegetation decreases, the surface temperature increases.
\end{abstract}

Keyword: Urban Heat Island, Surface Temperature Increase, Vegetation Density, Building Density.

\footnotetext{
* Corresponding author. Sri Rahayu.

E-mail address: sri.yksmg@yahoo.com.
} 


\section{Pendahuluan}

Isu lingkungan utama yang tengah dihadapi setiap negara di dunia yaitu Pemanasan global (global warming). Pemanasan global dalam hal ini berhubungan dengan suatu kondisi terjadinya peningkatan suhu rata-rata permukaan bumi. Pemanasan global merupakan kejadian yang tidak dapat dipisahkan dari aktivitas manusia. Salah satunya adalah dampak dari pembangunan dan perkembangan kota-kota di seluruh dunia khususnya di Indonesia.

Meningkatnya pembangunan infrastruktur dan berkurangnya vegetasi yang berfungsi menyerap panas menyebabkan terjadinya peningkatan suhu permukaan. Meningkatnya tutupan lahan permukiman akan mempengaruhi kerapatan vegetasi dalam sebuah kota. Akibat keterbatasan luas lahan, alih fungsi lahan yang dilakukan untuk memenuhi kebutuhan ruang aktivitas cenderung mengurangi luasan lahan hijau. Berkurangnya proporsi lahan hijau tersebut akan menyebabkan terjadinya perubahan pada pola spasial wilayah yang berdampak pada peningkatan suhu udara perkotaan secara signifikan (Akbari dkk, 2016). Faktor-faktor diatas seperti berkurangnya kerapatan vegetasi membuat suhu permukaan di perkotaan terasa lebih panas. Fenomena ini dinamakan dengan Urban Heat Island (UHI). Pengertian UHI yaitu fenomena peningkatan suhu udara sekitar $3-10^{\circ} \mathrm{C}$ yang terjadi pada suatu wilayah perkotaan dibandingkan daerah sekitarnya. Perubahan penggunaan lahan dari vegetasi menjadi lahan terbuka non vegetasi seperti daerah beraspal, beton dan lahan terbangun merupakan penyebab terjadinya fenomena ini. Dampak yang muncul akibat UHI berupa peningkatan polusi udara, mengakibatkan degradasi kualitas udara dan lingkungan yang terdegradasi secara signifikan. Jika penambahan lahan terbangun terus dilakukan tanpa adanya upaya mengimbangi dengan vegetasi yang cukup, maka suhu permukaan perkotaan akan semakin mengalami peningkatan. Oleh karen itu dalam penelitian ini bertujuan untuk mengetahui hubungan antara kerapatan vegetasi dan bangunan terhadap UHI (Urban Heat Island) yang terjadi di Kota Magelang.

\section{Metode}

Metode yang digunakan untuk meneliti hubungan kerapatan vegetasi dan bangunan terhadap UHI (urban Heat Island) di Kota Magelang yaitu dengan metode penelitian kuantitatif. Penelitian ini mengarah pada studi hubungan atau korelasi dari variabel-variabel yang digunakan. Keluaran dari penelitian ini yaitu hubungan perubahan suhu permukaan dengan perubahan tutupan lahan. Perubahan suhu permukaan di identifikasi menggunakan informasi mengenai kenaikan rata-rata suhu permukaan pada tiap kelas tutupan lahan; serta formula OLS (Ordinary Least Square) berbasis spasial antara perubahan kerapatan bangunan $\left(\mathrm{x}_{1}\right)$ dan kerapatan vegetasi $\left(\mathrm{x}_{2}\right)$ tahun 2000 hingga 2016 terhadap suhu permukaan (y). Dalam prosesnya, data spasial digital yang telah diperoleh selanjutnya akan diproses menggunakan teknik SIG dan penginderaan jauh. Data input yang digunakan untuk kajian berupa rekaman informasi dari citra dalam bentuk nilai spektral, diantaranya identifikasi tutupan lahan, kerapatan bangunan, identifikasi kerapatan vegetasi.

\subsection{Metode Pengumpulan Data}

- Interpretasi citra

Interpretasi citra dilakukan untuk memperoleh informasi tutupan lahan dari data citra Landsat tahun 2000, 2009 dan 2016 di Kota Magelang. Data-data citra tersebut diperoleh dari USGS. Interpretasi dilakukan melalui teknik klasifikasi tidak terbimbing dengan menggunakan metode Iso Cluster Classification. Pada proses ini akan diperoleh kelas penutupan lahan tentatif. Interpretasi tutupan lahan ini merujuk pada hierarki tutupan lahan level 4, yaitu klasifikasi tutupan lahan menurut Peraturan Direktur Jenderal Planologi Kehutanan No. P.1/VII-IPSDH/2015 tentang Pemantauan Penutupan lahan.

- Uji Ketelitian Interpretasi

Uji ketelitian interpretasi dilakukan untuk memvalidasi data hasil interpretasi dengan kenyataan yang ada di lapangan. Kegiatan ini dilakukan untuk melihat kondisi tutupan lahan, kerapatan vegetasi, kerapatan bangunan serta suhu permukaan di lapangan. Berdasarkan tabel hasil survey lapangan, dapat diketahui nilai keakuratan interpretasinya menggunakan rumus:

Uji ketelitian interpretasi $(\%)=\frac{\sum \mathrm{f}_{\mathrm{i}} y s_{\mathrm{s}}}{\sum \mathrm{\hbar}_{\mathrm{i}} y{ }^{2}} \times 100 \%$ 
Analisis spasial dilakukan dengan menggunakan bantuan Sistem Informasi Geografis (SIG) melalui tools NDVI (Normalized Difference Vegetation Index), NDBI (Normalized Difference Building Index) dan LST (Land Surface Temperature) Interpretasi kelas masingmasing variabel dibagi menjadi kelas sangat tinggi, kelas tinggi, kelas sedang, kelas rendah dan kelas sangat rendah.

Analisis NDVI bertujuan untuk mengetahui kelas kerapatan vegetasi berdasarkan data citra penginderaan jauh. Berikut merupakan tahapan analisis NDVI dalam penelitian ini:

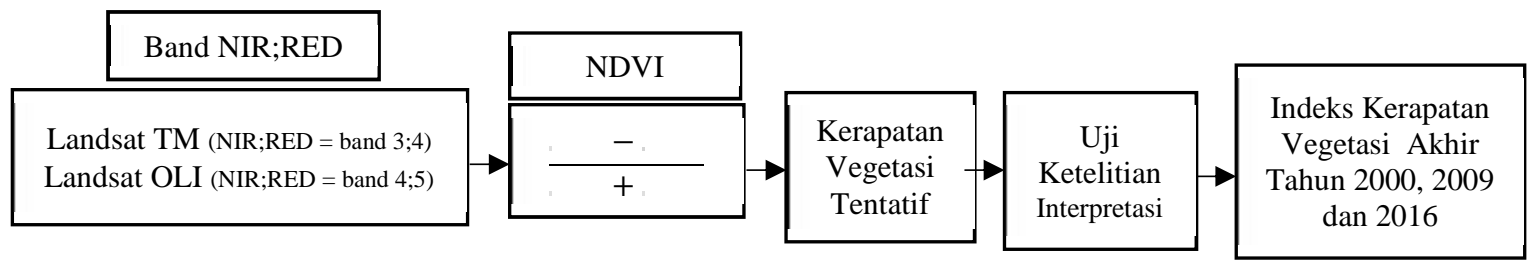

Analisis NDBI bertujuan untuk mengetahui kelas kerapatan bangunan berdasarkan data citra penginderaan jauh. Berdasarkan beda kerapatan tersebut maka dapat diinterpretasikan jenis kerapatan bangunannya. Berikut merupakan tahapan analisis NDVI dalam penelitian ini:

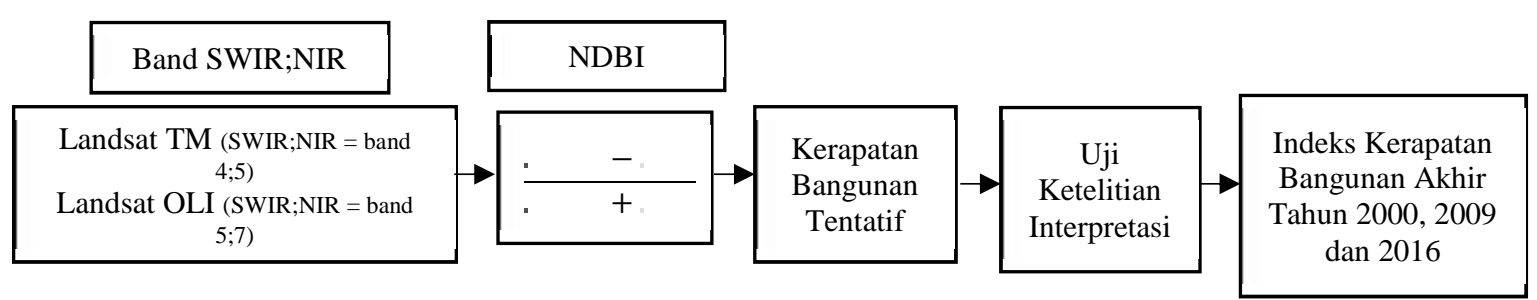

Analisis LST bertujuan untuk mengetahui kelas suhu permukaan berdasarkan data citra penginderaan jauh. Berdasarkan perbedaan suhu tersebut tersebut maka dapat diinterpretasikan suhu permukaannya. Berikut merupakan tahapan analisis LST dalam penelitian ini:

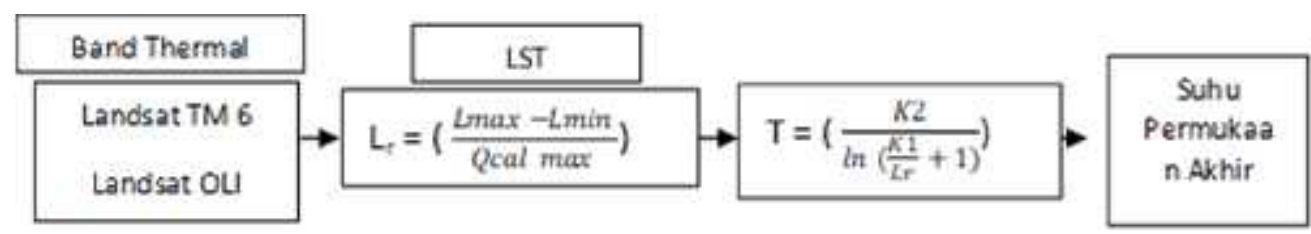

Mengeksplorasi hubungan spasial antara variabel dependent dengan variable independent dapat dilakukan menggunakan permodelan hubungan antar variabel dari Regresi Linear Berganda menggunakan tools OLS.

\section{Hubungan Kerapatan Vegetasi dan Bangunan terhadap UHI (Urban Heat Island)}

Tingginya permintaan lahan yang terjadi pada wilayah perkotaan, membuat luasan lahan terbangun semakin meningkat pesat. Dampaknya berakibat pada suhu permukaan di sebuha kota akan terasa lebih panas. Hal ini disebabkan oleh proporsi vegetasi yang menurun seiring terjadinya perubahan guna lahan. Fenomena ini dapat dikatakan sebagai fenomena Urban Heat Island (UHI), yaitu terkonsentrasinya panas di pusat kota akibat banyaknya tutupan permukaan yang mudah menangkap kalor (Akbari \& Kolokotsa 2016).

Perkembangan kota yang semakin meningka dapat memicu kompetisi penggunaan lahan yang pada akhirnya akan mendesak keberadaan ruang terbuka hijau sebagai unsur pengatur suhu mikro perkotaan. Ruang terbuka hijau akan beralih fungsi menjadi permukiman, jasa-jasa, bisnis, perkantoran, industri ataupun gedung-gedung lainnya. Ruang dengan vegetasi alami akan 
tergantikan dengan permukaan kawasan yang sulit terevaporasi seperti aspal, dan beton. Kondisi ini akan memicu terjadi kontrasnya radiansi permukaan dan kecenderungan kenaikan suhu permukaan kota menjadi lebih tinggi. (Weng dkk. 2004).

Sebuah alat ukur yang digunakan untuk menganalisa kecerahan digital dalam melakukan penelitian tentang biomassa dan vegetatif yaitu Vegetation Index (VI) atau Indeks Vegetasi. Nilai kecerahan digital dipengaruhi oleh besarnya gelombang yang diterima alat rekam digital. Indeks Vegetasi yang sering digunakan yairu Normalized Difference Vegetation Index (NDVI). Indeks vegetasi atau NDVI digunakan untuk menggambarkan tingkat kehijauan suatu tanaman pada sebuah wilayah. Indikator keberadaan dan kondisi vegetasi sejak dulunya diperoleh menggunakan kombinasi matematis antara band merah dan band NIR (Near-Infrared Radiation) (Lillesand dan Kiefer 1997).

Sementara itu, untuk pemetaan daerah urban dapat dilakukan melalui citra Landsat TM dan Landsat OLI mengggunakan indeks Normalized Difference Built-up Index (NDBI) dan UI (Urban Index). Indeks tersebut sangat sensitif terhadap lahan terbangun/lahan terbuka yang dapat menonjolkan kenampakan lahan terbangun dibandingkan dengan obyek yang lainnya. Dalam pemetaan menggunakan NDBI akan memanfaatkan band inframerah dekat dan inframerah tengah. Dimana Nilai rentang spektral NDBI yang digunakan berkisar antara 0,1 - 0,3 (As Syakur, 2012 dalam Mutiah et al, 2017).

Mengetahui arah hubungan antara variabel independen dengan variabel dependen diperoleh menggunakan analisis regresi linier berganda. Hasil analisis yang diperoleh merupakan hubungan secara linear antara dua atau lebih variabel independen $\left(\mathrm{x}_{1}, \mathrm{x}_{2}, \ldots . \mathrm{x}_{\mathrm{n}}\right)$ dengan variabel dependen (Y). Dalam analisis ini, arah hubungan antara variabel independen dengan variabel dependen memiliki hubungan positif atau negatif yang akan berpengaruh pada prediksi nilai dari variabel dependen apabila nilai variabel independen mengalami kenaikan atau penurunan (Xu dkk., 2011). Persamaan regresi linear berganda sebagai berikut:

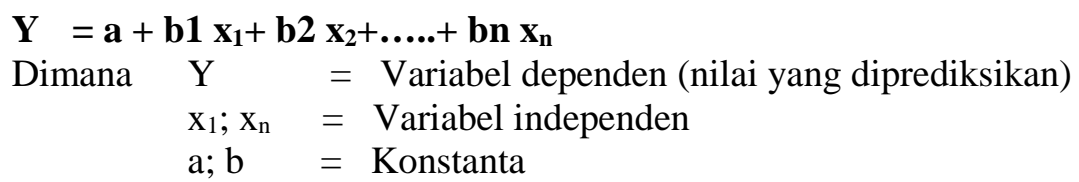

\section{Hasil dan Pembahasan}

\subsection{Analisis NDVI Tahun 2000, 2009 dan 2016}

Interpretasi kerapatan vegetasi tersebut dilakukan menggunakan analisis NDVI sesuai dengan algoritma dengan memanfaatkan band NIR dan RED. Nilai kerapatan vegetasi tersebut kemudian diklasifikasikan ke dalam 5 kelas. Kelas kerapatan vegetasi dapat dilihat pada tabel 1 di bawah ini.

Tabel 1. Kelas Kerapatan Vegetasi (Analisis Penyusun, 2019)

\begin{tabular}{cc}
\hline Kategori Kerapatan & Indeks Kerapatan Vegetasi \\
\hline Sangat Tinggi & $>0.4$ \\
Tinggi & $0,3-0,4$ \\
Sedang & $0,2-0,3$ \\
Rendah & $0,1-0,2$ \\
Sangat Rendah & $<0,1$
\end{tabular}

Semakin tinggi kelas kerapatan vegetasi menggambarkan bahwa jenis tutupan lahannya memiliki vegetasi yang padat. Tutupan lahan hutan tanaman termasuk dalam kelas karapatan tinggi dikarenakan jenis vegetasi di dalamnya merupakan vegetasi kayu dengan karakteristik daun yang lebat. Sebaliknya, semakin rendah kelas kerapatan vegetasi maka merepresentasikan bahwa jenis tutupan lahannya memiliki vegetasi yang jarang bahkan tidak terdapat vegetasi. Secara spasial yaitu pola persebaran kerapatan vegetasi Kota Magelang dapat dilihat pada gambar 1 di bawah ini. 

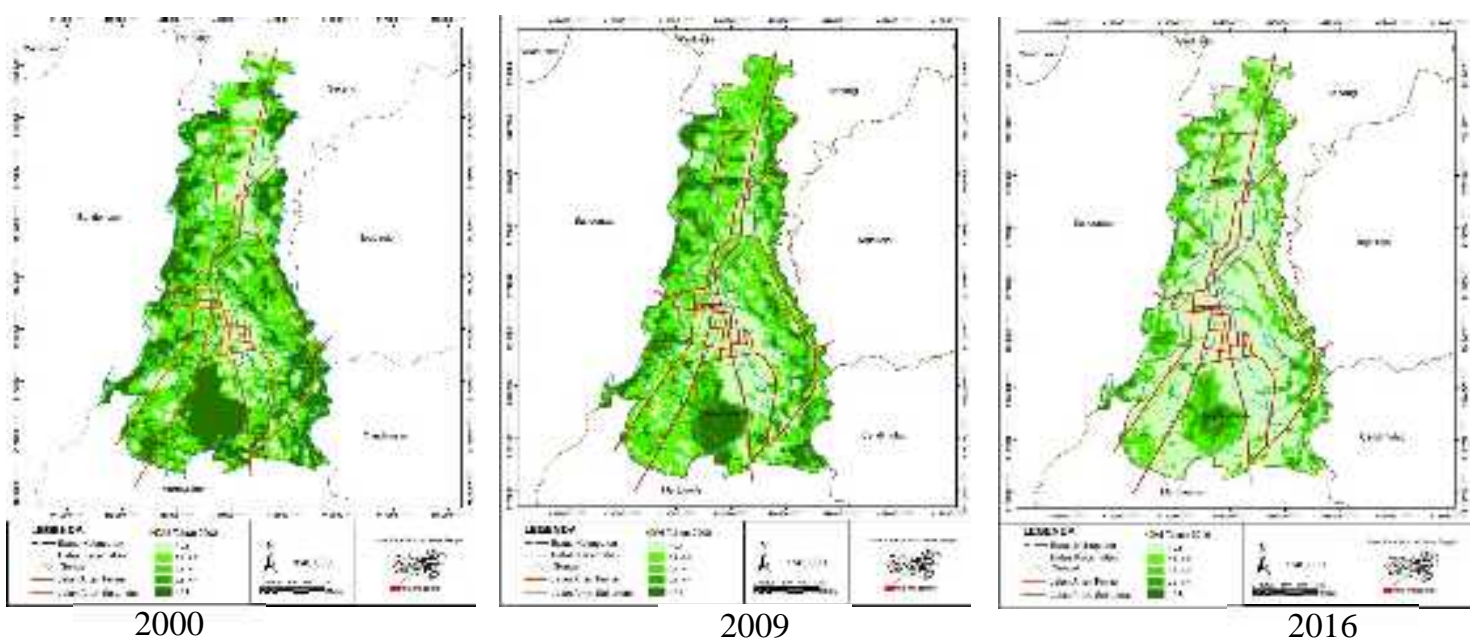

Gambar 1. Peta Kerapatan Vegetasi Tahun 2000, 2009 dan 2016 (Analisis Penyusun,2019)

Berdasarkan pengolahan terkait kerapatan vegetasi secara time series, dapat diketahui bahwa perubahan kerapatan vegetasi pada tahun 2000 hingga tahun 2009 kelas vegetasi yang mengalami pengurangan vegetasi adalah kelas kerapatan vegetasi sangat tinggi dan kelas vegetasi tinggi. Kelas Penurunan luasan vegetasi sebesar $-325,07$ ha dan $-54,62$ ha. Pada rentang tahun 2009 hingga tahun 2016 kelas vegetasi sangat tinggi dan kelas vegetasi tinggi juga mengalami penurunan dengan jumlah luasan sebesar $-116,55$ ha dan $-70,72$ ha, meskipun perubahan jumlahnya tidak sebesar pada tahun 2000 hingga tahun 2009. luas perubahannya dapat dilihat pada Tabel 2 di bawah ini.

Tabel 2. Luas Perubahan Kerapatan Vegetasi (Analisis Penyusun, 2019)

\begin{tabular}{lrrrr}
\hline Kerapatan Vegetasi & $\mathbf{2 0 0 0}$ & $\mathbf{2 0 0 9}$ & $\mathbf{2 0 1 6}$ & $\begin{array}{c}\text { Perubahan } \\
\text { (ha) }\end{array}$ \\
& 517.7441 & 192.6717 & 76.1147 & -441.6294 \\
Sangat Tinggi & 299.6175 & 244.9929 & 174.2714 & -125.3461 \\
Tinggi & 334.9336 & 369.1552 & 344.5035 & 9.5699 \\
Sedang & 415.311 & 601.6666 & 703.7373 & 288.4263 \\
Rendah & 261.0886 & 420.2084 & 530.0679 & 268.9793 \\
Sangat Rendah & 1828.6948 & 1828.6948 & 1828.6948 & 0 \\
Total & & & &
\end{tabular}

Peta perubahan kerapatan vegetasi diketahui bahwa semakin hijau warnanya, perubahan kerapatan vegetasinya tinggi dan semakin merah warnanya, perubahan kerapatan vegetasinya semakin rendah. Perubahan kerapatan vegetasi Kota Magelang pada tahun 2000 hingga tahun 2016 paling banyak terjadi di tengah kota yang paling dominan adalah kerapatan vegetasi tinggi dan sangat tinggi. 


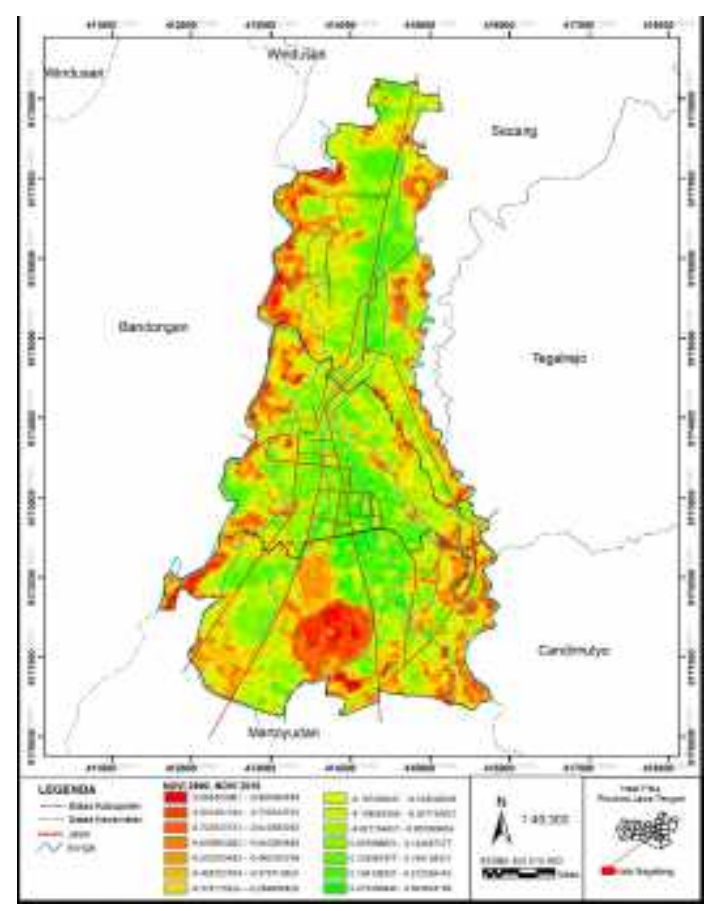

Gambar 2. Peta Perubahan Kerapatan Vegetasi Tahun 2000 - 2016 (Analisis Penyusun, 2019)

\subsection{Analisis NDBI Tahun 2000, 2009 dan 2016}

Kerapatan bangunan pada Kota Magelang Tahun 2000 dan 2009 diperoleh melalui pengolahan Citra Landsat TM, sedangkan kerapatan bangunan tahun 2016 diperoleh melalui pengolahan Citra Landsat 8. Interpretasi kerapatan bangunan tersebut dilakukan menggunakan analisis NDBI sesuai dengan algoritma dengan memanfaatkan band SWIR dan NIR dan. Nilai kerapatan bangunan tersebut kemudian diklasifikasikan ke dalam 5 kelas. Kelas kerapatan bangunan dapat dilihat pada Tabel.3 di bawah ini.

Tabel 3 Kelas Kerapatan Bangunan (Analisis Penyusun, 2019)

\begin{tabular}{cc}
\hline Kategori Kerapatan & Indeks Kerapatan Bangunan \\
\hline Sangat Tinggi & $>0.3$ \\
Tinggi & $0,2-0,3$ \\
Sedang & $0,1-0,2$ \\
Rendah & $0-0,1$ \\
Sangat Rendah & $<0$
\end{tabular}

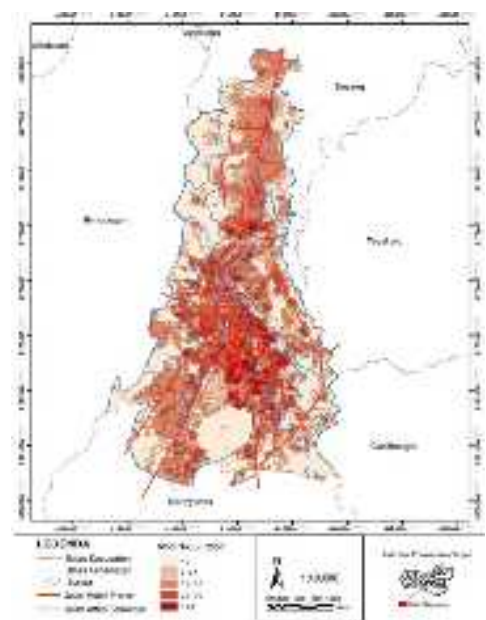

2000

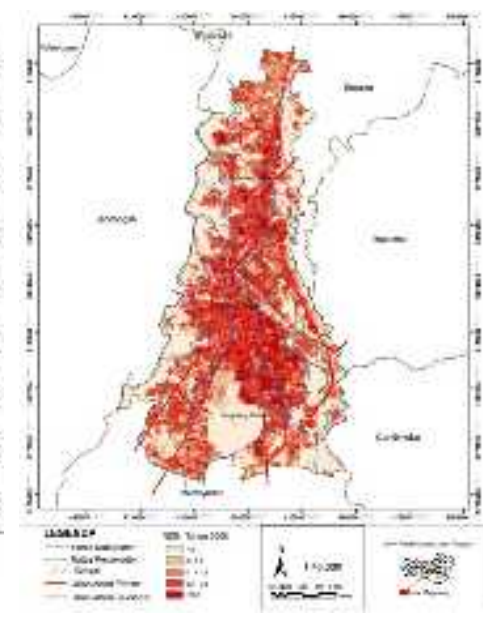

2009

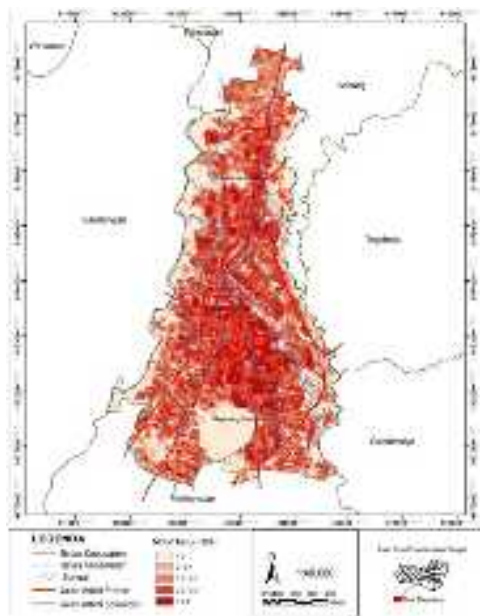

2016

Gambar 3. Peta Kerapatan Bangunan Tahun 2000, 2009 dan 2016 (Analisis Penyusun, 2019) 
Semakin tinggi kelas kerapatan bangunan menggambarkan bahwa jenis tutupan lahannya memiliki kerapatan bangunan yang rapat. Secara spasial yaitu pola persebaran kerapatan bangunan Kota Magelang dapat dilihat pada gambar 3. Berdasarkan hasil pengolahan terkait, kerapatan bangunan secara time series dapat diketahui perubahan kerapatan bangunan pada tahun 2000 hingga tahun 2009 mengalami peningkatan jumlah luasan yaitu kelas kerapatan bangunan tinggi dan kerapatan bangunan sangat tinggi. Kelas kerapatan bangunan tinggi dan sangat tinggi mengalami peningkatan jumlah luasan sebesar 559,21 ha dan 325,11 ha. Kondisi ini terjadi dikarenakan penambahan lahan permukiman yang mengalami kenaikan signifikan dan penurunan tutupan vegetasi pada periode tahun 2000 hingga tahun 2009. Pada rentang tahun 2009 hingga tahun 2016 kelas kerapatan bangunan sangat tinggi dan tinggi juga mengalami peningkatan dengan jumlah luasan sebesar 325,11 ha dan 559,21 ha, perubahan jumlah luasan meningkat lebih besar dibandingkan pada tahun 2000 hingga tahun 2009. Luas perubahan pertahun dapat dilihat pada tabel 4 dan perubahan kerapatan bangunan dapat dilihat pada gambar 4 di bawah ini.

Tabel 4. Luas Perubahan Kerapatan Bangunan (Analisis Penyusun, 2019)

\begin{tabular}{llllll}
\hline Kerapatan Bangunan & \multicolumn{3}{c}{ Luas (ha) } & \multicolumn{2}{c}{ Perubahan } \\
& \multicolumn{1}{c}{$\mathbf{2 0 0 0}$} & $\mathbf{2 0 0 9}$ & $\mathbf{2 0 1 6}$ & \\
\hline Sangat Tinggi & 67.9613 & 137.2492 & 393.0717 & 325.1104 \\
Tinggi & 228.6805 & 511.6053 & 787.8926 & 559.2121 \\
Sedang & 516.6256 & 426.0919 & 420.5802 & -96.0454 \\
Rendah & 357.081 & 351.0471 & 87.6138 & -269.4672 \\
Sangat Rendah & 658.3464 & 402.7013 & 139.5365 & -518.8099 \\
\hline Total & 1828.6948 & 1828.6948 & 1828.6948 & 0 \\
\hline
\end{tabular}

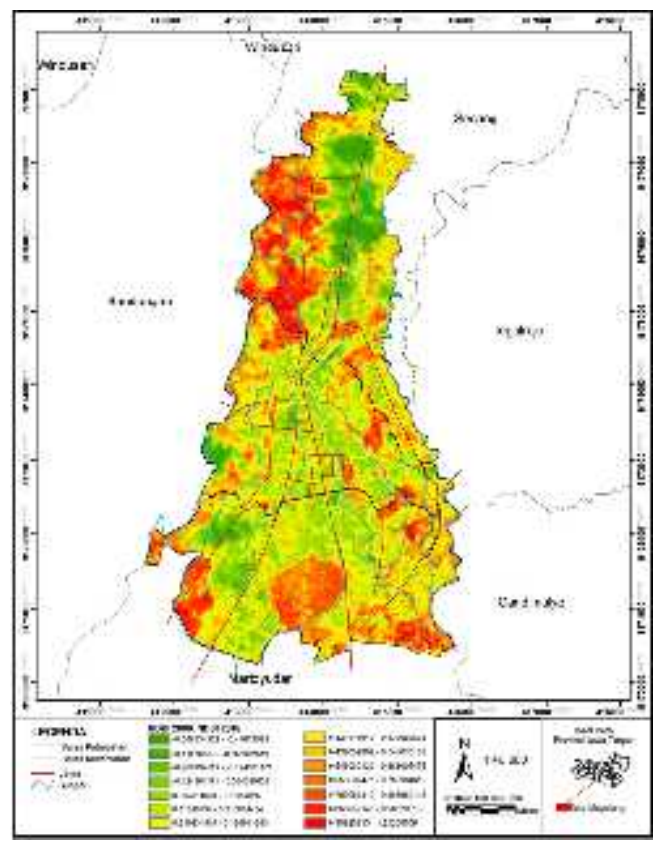

Gambar 4. Peta Perubahan Kerapatan Bangunan Tahun 2000 - 2016 (Analisis Penyusun, 2019)

Peta perubahan kerapatan bangunan di atas diketahui bahwa semakin hijau warnanya, perubahan kerapatan bangunannya rendah dan semakin merah warnanya, perubahan kerapatan bangunan semakin tinggi. Perubahan kerapatan bangunan Kota Magelang pada tahun 2000 hingga tahun 2016 paling banyak terjadi di Kecamatan Magelang Utara di dominasi oleh kerapatan bangunan tinggi dari sangat tinggi. 


\section{3}

Interpretasi suhu permukaan tersebut dilakukan menggunakan analisis LST sesuai dengan algoritma dengan memanfaatkan band thermal dari Citra Landsat TM. Hasil analisis LST tersebut kemudian diklasifikasikan ke dalam 5 kelas. Kelas LST dapat dilihat pada tabel 5 di bawah ini.

Tabel 5. Kelas Kerapatan Bangunan (Analisis Penyusun, 2019)

\begin{tabular}{cc}
\hline Kelas Suhu & Suhu Permukaan $\left({ }^{\circ} \mathrm{C}\right)$ \\
\hline Sangat Rendah & $<21^{\circ} \mathrm{C}$ \\
Rendah & $21^{\circ} \mathrm{C}-23^{\circ} \mathrm{C}$ \\
Sedang & $23^{\circ} \mathrm{C}-25^{\circ} \mathrm{C}$ \\
Tinggi & $25^{\circ} \mathrm{C}-27^{\circ} \mathrm{C}$ \\
Sangat Tinggi & $>27^{\circ} \mathrm{C}$
\end{tabular}

Suhu permukaan dihasilkan dari analisis LST dengan menggunakan band termal Citra Landsat. Semakin tinggi kelas suhu permukaan di satu wilayah maka suhu permukaannya semakin panas begitu juga sebaliknya. Secara spasial, pola persebaran suhu permukaan Kota Magelang dapat dilihat pada gambar 5 di bawah ini

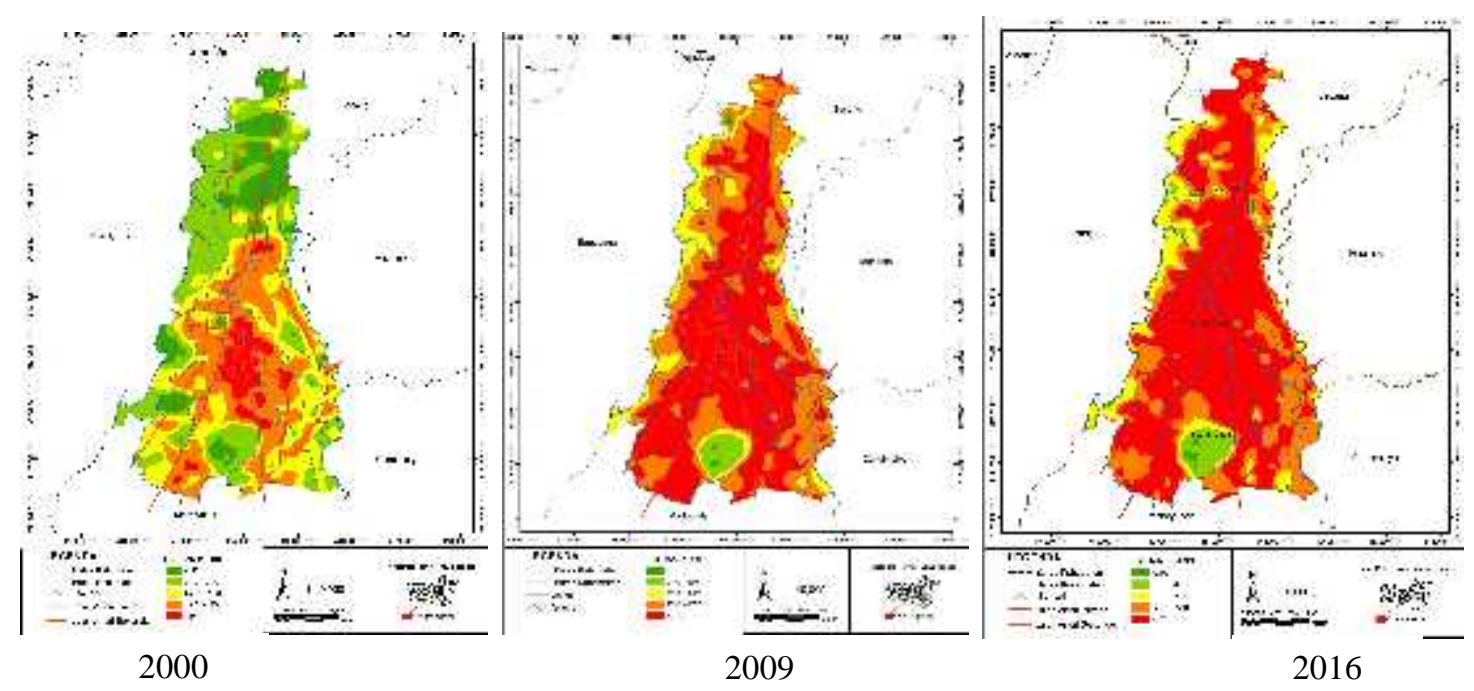

Gambar 5. Peta Suhu Permukaan Tahun 2000, 2009 dan 2016 (Analisis Penyusun, 2019)

Pada gambar di atas memberikan informasi bahwa luasan suhu permukaan untuk kelas sangat tinggi (lebih dari $\left.27^{\circ} \mathrm{C}\right)$ dan kelas suhu permukaan tinggi $\left(25^{\circ} \mathrm{C}\right.$ hingga $\left.27^{\circ} \mathrm{C}\right)$ naik tiap periode tahunnya, sedangkan kelas yang lain mengalami fluktuatif. Sementara itu untuk tahun 2009 dan 2016 yang membedakan dari jumlah kelas suhu permukaan sangat tinggi lebih besar luasannya dibandingkan dengan kelas suhu permukaan tinggi serta kelas suhu permukaan tinggi mengalami penurunan pada tahun 2016. Hal tersebut mengindikasikan bahwa secara spasial kelas suhu tinggi beralih ke kelas suhu permukaan sangat tinggi. Luasan lahan terbangun meningkat dengan konversi lahan juga meningkat dalam jumlah besar, maka suhu permukaan akan meningkat pula. 
Tabel 6 Luas Perubahan Suhu Permukaan (Analisis Penyusun, 2019)

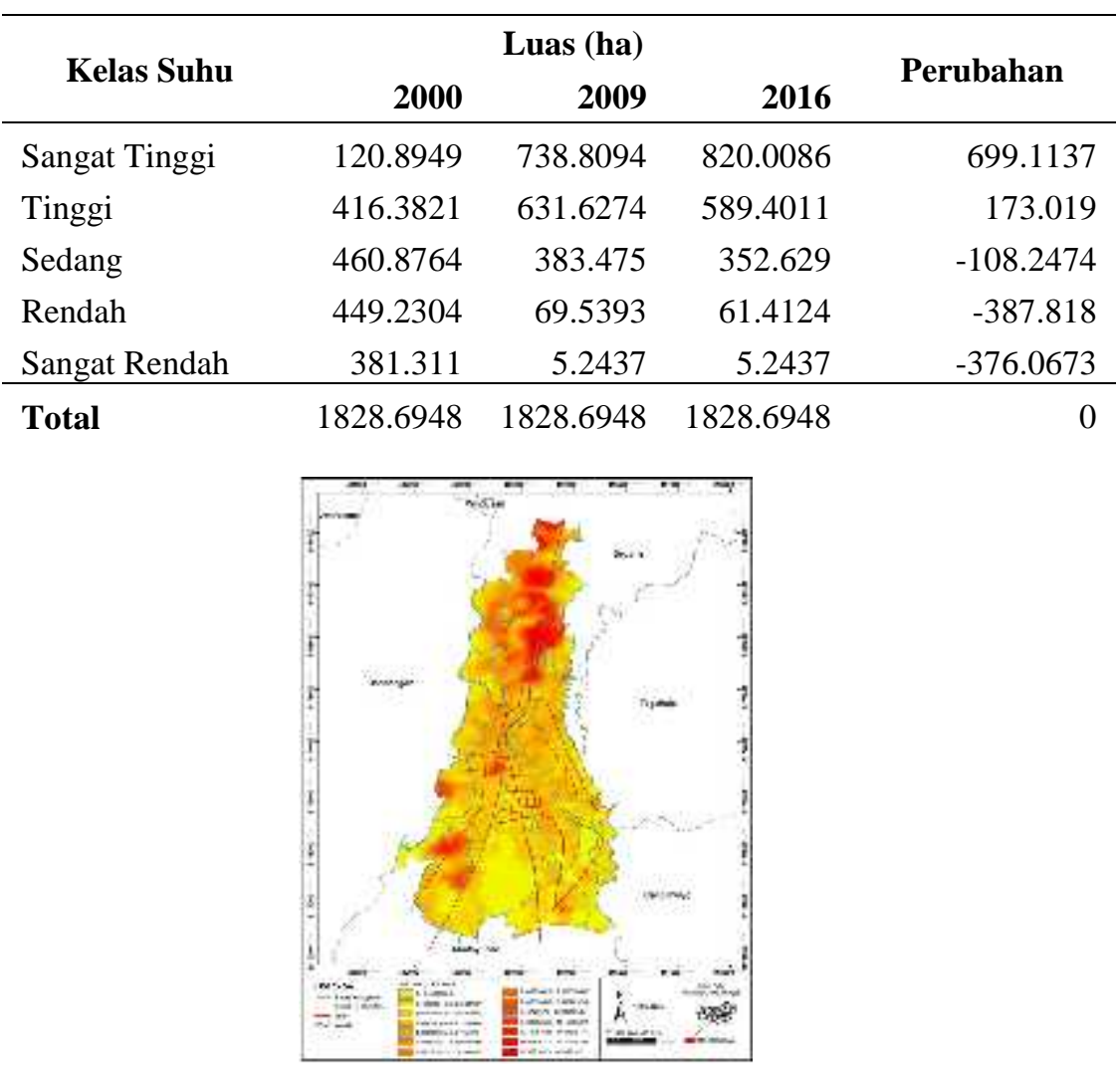

Gambar 6. Peta Perubahan Suhu Permukaan Tahun 2000 - 2016 (Analisis Penyusun, 2019)

Peta perubahan suhu permukaan di atas diketahui bahwa semakin merah warnanya, perubahan suhu permukaannya tinggi dan semakin kuning warnanya, perubahan suhu permukaan semakin rendah. Perubahan suhu permukaan Kota Magelang pada tahun 2000 hingga tahun 2016 paling banyak terjadi di Kecamatan Magelang Utara yang di dominasi oleh suhu permukaan tinggi dan sangat tinggi.

\subsection{Hubungan antara kerapatan vegetasi, kerapatan bangunanan dan UHI}

Identifikasi hubungan antara kerapatan vegetasi (NDVI), kerapatan bangunan (NDBI) dan suhu permukaan (LST) dilakukan dengan menggunakan pendekatan $O L S$ yang kemudian didapatkan formula regresi berganda sebagai berikut:

$$
\begin{array}{ll}
\mathrm{Y} & : 5,61 \mathrm{X}_{1}-1,34 \mathrm{X}_{2}+2,47 \\
\mathrm{Y} & : \text { perubahan suhu permukaan }\left({ }^{\circ} \mathrm{C}\right) \\
\mathrm{X}_{1} & : \text { perubahan indeks kerapatan bangunan (NDBI) } \\
\mathrm{X}_{2} & : \text { perubahan indeks kerapatan vegetasi (NDVI) }
\end{array}
$$

Berdasarkan formula di atas maka diketahui bahwa hubungan antara perubahan suhu permukaan dengan perubahan indeks kerapatan bangunan Kota Magelang yaitu berbanding lurus. Saat perubahan indeks kerapatan bangunan meningkat, maka suhu permukaan akan meningkat pula. Sebaliknya hubungan antara perubahan kerapatan suhu permukaan dengan perubahan indeks kerapatan vegetasi di Kota Magelang adalah berbanding terbalik. Jika perubahan indeks vegetasi menurun, maka suhu permukaan mengalami peningkatan. Tingkat kevalidan dari OLS menghasilkan R Square adusted sebesar 0,648. Artinya, kerapatan vegetasi dan bangunan terhadap suhu permukaan memiliki pengaruh sebesar $65 \%$. Atau dengan kata lain ada $35 \%$ faktor lain yang mempengaruhi. Selanjutnya scatterplot yang menunjukkan persebaran data tiap variabel dapat dilihat pada gambar 7 dibawah ini. 

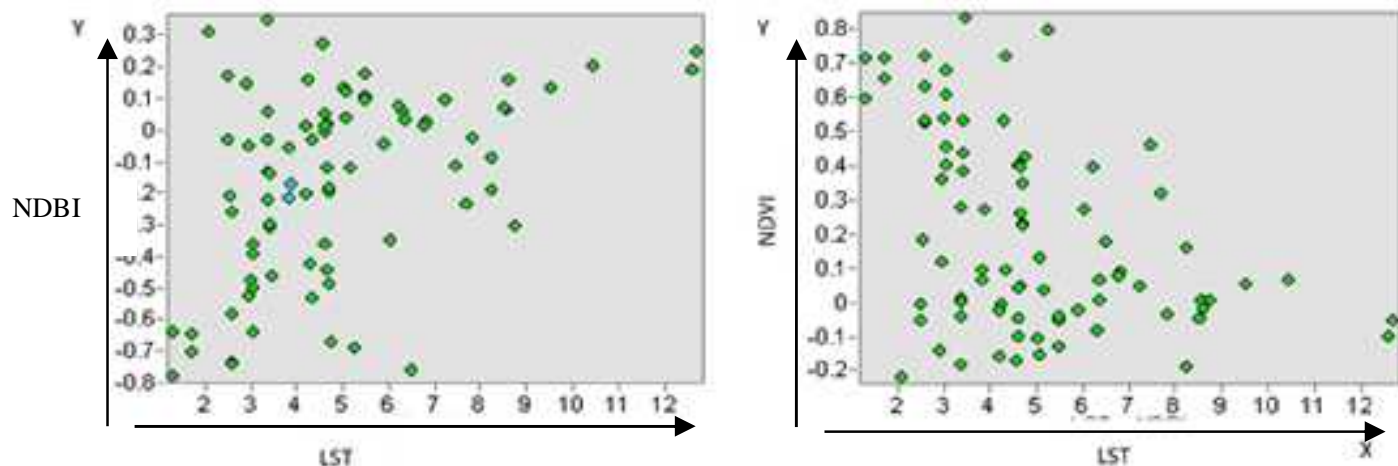

Gambar 7 Persebaran Data Kerapatan Vegetasi, Kerapatan Bangunan, dan Suhu Permukaan Kota Magelang (Analisis Penyusun, 2019)

Berdasarkan gambar scatterplot dapat diketahui bahwa persilangan antara perubahan suhu permukaan dengan kerapatan vegetasi menunjukkan pola hubungan berupa Y bernilai besar dan $\mathrm{X}$ bernilai kecil, artinya hubungan antara kedua variabel tersebut bersifat negatif. Sebaliknya persilangan antara perubahan suhu permukaan dengan kerapatan bangunan menunjukkan pola hubungan berupa $\mathrm{Y}$ bernilai besar dan $\mathrm{X}$ bernilai besar, artinya hubungan antara dua variabel positif. jika dilihat dari pola hubungannya, hubungan antara kerapatan vegetasi, kerapatan bangunan dan suhu permukaan di Kota Magelang pada tahun 2000 hingga tahun 2016 yaitu, signifikan mengelompok dengan nilai Zscore sebesar 3,49 dan $p$ value sebesar 0,047 artinya daerah-daerah yang memiliki hubungan kuat memiliki pola mengelompok terpusat pada bagian tengah Kota Magelang. Hal ini menunjukkan bahwa suhu permukaan di Kota Magelang lebih tinggi dibandingkan dengan suhu permukaan di daerah pinggiran kota, yang menyebabkan terjadinya UHI.

\section{Kesimpulan}

Peningkatan suhu permukaan di Kota Magelang terjadi seiring dengan perkembangan dan perubahan fisik kota yang dipengaruhi oleh meningkatnya kerapatan bangunan sebesar 325,11 ha dan berkurangnya kerapatan vegetasi 441,62 ha dari tahun 2000 hingga tahun 2016. Suhu permukaan rata-rata Kota Magelang mengalami peningkatan dari $22,58{ }^{\circ} \mathrm{C}$ pada tahun 2000 menjadi $27,11^{\circ} \mathrm{C}$ pada tahun 2016 . Hubungan antara suhu permukaan terhadap kerapatan vegetasi dan bangunan diketahui melalui formula OLS yang dihasilkan yaitu $Y=\mathbf{5 , 6 1} \mathbf{X}_{\mathbf{1}} \mathbf{- 1 , 3 4}$ $\mathbf{X}_{\mathbf{2}}+\mathbf{2 , 4}$ dengan Rsquare adusted sebesar 0,648, dimana y adalah suhu permukaan, $\mathrm{x} 1$ adalah kerapatan bangunan dan $\mathrm{x} 2$ adalah kerapatan vegetasi. Kerapatan bangunan berkorelasi positif dengan suhu permukaan dan kerapatan vegetasi berkorelasi negatif dengan suhu permukaan. Artinya, jika karapatan bangunan meningkat dan kerapatan vegetasi berkurang, maka suhu permukaan meningkat. Persebaran suhu permukaan sangat tinggi mengelompok di tengah dan suhu permukaan rendah berada di pinggiran kota, hal ini membuat terjadinya fenomena UHI di Kota Magelang.

\section{Referensi}

Akbari, H., \& Kolokotsa, D. (2016). Three Decades Of Urban Heat Islands And Mitigation Technologies Research Three Decades Of Urban Heat Islands And Mitigation Technologies Research. Energy \& Buildings. https://doi.org/10.1016/j.enbuild.2016.09.067

Hidayati, I.N., 2013. Analisis Transformasi Citra Dan Penggunaan/Penutup Lahan Terhadap Urban Heat Island Berbasis Citra Penginderaan Jauh. Kartografi dan Penginderaan Jauh UGM. Available at: geo.ugm.ac.id.

Kotharkar, R., \& Bagade, A. (2018). Evaluating urban heat island in the critical local climate zones of an Indian city. Landscape and Urban Planning, 169 (December 2016), 92-104. ttps://doi.org/10.1016/j.landurbplan.2017.08.009

Lillesand T.M \& R.W. Kiefer. (1997). Penginderaan Jauh dan Interpretasi Citra. Diterjemahkan: Dulbahri, Prapto Suharsono, Hartono, Suharyadi. Yogyakarta: Gajah Mada University Press 
Mohajerani, A., Bakaric, J., \& Jeffrey-Bailey, T. (2017). The urban heat island effect, its causes, and mitigation, with reference to the thermal properties of asphalt concrete. Journal of Environmental Management, 197, 522-538. https://doi.org/10.1016/j.jenvman.2017.03.095

Mutiah et al. (2017). Analisis Hubungan Antara Perubahan Suhu Dengan Indeks Kawasan Terbangun Menggunakan Citra Landsat (Studi Kasus : Kota Surakarta). Volume 6, Nomor 4, Tahun 2017.

Peraturan Direktur Jenderal Planologi Kehutanan No. P.1/VII-IPSDH/2015 tentang Pemantauan Penutupan lahan.

Wang, S, Ma, Q, Ding, H., \& Liang, H. (2016). Detection Of Urban Expansion And Land Surface Temperature Change Using Multi-Temporal Landsat Images. Resources, Conservation and Recycling. https://doi.org/10.1016/j.resconrec.2016.05.0

Weng, Q, Lu, D, \& Schubring, J. (2004). Estimation Of Land Surface Temperature-Vegetation Abundance Relationship For Urban Heat Island Studies. Remote Sensing of Environment, 89(4), 467-483. https://doi.org/10.1016/j.rse.2003.11.005

Xu, Q. dkk., 2016. The Influence Of Rapid Urbanization And Land Use Changes On Terrestrial Carbon Sources/Sinks In Guangzhou, China. Ecological Indicators, 70, hal.304-316. Available at: http://dx.doi.org/10.1016/j.ecolind.2016.05.052. 